\title{
Implementation of Environmental-Based Schools in the Adiwiyata Program: A Literature Review
}

\author{
Fairuzzabadi Amrullah ${ }^{1, *}$ Heru Nurcahyo ${ }^{2}$ \\ ${ }^{1}$ Master of Biology Education, Faculty of Mathematics and Natural Sciences, Universitas Negeri Yogyakarta, \\ Indonesia \\ ${ }^{2}$ Department of Biology Education, Faculty of Mathematics and Natural Sciences, Universitas Negeri \\ Yogyakarta, Indonesia \\ *Corresponding author: fairuzzabadiamrullah.2019@student.uny.ac.id
}

\begin{abstract}
Environmental pollution can result in a decrease in environmental quality, resulting in disruption of the balance of the ecosystem and environmental degradation. Human behavior that lacks awareness and responsibility for the environment can result in environmental damage. In this case, to form a character that loves the environment, the government tries to create environmentally sound education. The first component of the Adiwiyata school program policy in an integrated manner can involve all school members. However, the implementation in the field has not been fully implemented by the school community. The second component concerns the implementation of an environment-based curriculum where teachers or educators are competent so that the development of quality learning is related to the environment. The third component is participatory-based environmental protection activities. Adiwiyata's implementation that participatory-based environmental activities have standards for carrying out protection activities. Environmental protection and management activities are carried out such as composter, nursery all of which involve all school members. component the fourth of environmentally friendly facilities management means environment-friendly of a special allocation from Adiwiyata which is included in the school budget eco-friendly Facility arising from the purchase or grants from the agency.
\end{abstract}

Keywords: Adiwiyata, Policy, Enviromental

\section{INTRODUCTION}

Pollution and environmental damage can result in a decrease in the quality of the existing environment. The state of the environment is now facing a severe threat with large-scale air-water, sound and other types of pollution leading to global warming, climate change and loss of biodiversity, the possible impact it might make on a future generation. The degradation is caused by a severe environmental crisis [1], [2]. Such environmental damage is caused by human activities. Environmental education is an effort to provide environmental knowledge among students. It can be assumed that if knowledge about the environment increases, the environmental care behavior will increase and can reduce damage to the surrounding environment. Environmental management is an effort to maintain the balance of existing natural resources. These efforts are intended to not only be enjoyed by the present generation, but future generations can still enjoy it.
The case of environmental damage that occurs is rooted in human views and behavior towards the natural environment. Human behavior that lacks awareness and responsibility for the environment has resulted in damage environment. The implementation of environmental education is carried out by organizing an environmentally sound school or Adiwiyata school [3]. The State Ministry of Environment in 2006 launched the program Adiwiyata as a follow-up to the MoU on 3 June 2005 between the State Minister for the Environment and the Minister of Education. and Culture [4]. Green schools are the physical outcome of the planning, design, and construction process. The main focus of this process is to reinforce optimal learning, goals that are very much in line with the parallel goals of resource efficiency and minimal pollution [5]. The supporting factors for policy implementation are a). persistence of the principal; b). awareness and understanding of all school members of the importance of protecting the environment, c). There is an Adiwiyata team that works systematically and in a theme an interesting environment [6]. 
However, in implementing environmental-based school policies there are obstacles in its implementation. Where school residents still do not have a sense of love and awareness of keeping the school environment clean. Management of environmentally friendly facilities that involve school members who have not maximally, and the application of environment-based learning

\section{METHODS}

In order to provide an overview of existing research and to confirm this, a literature review was conducted by selecting articles from peer-reviewed journals published in the last 20 years. A systematic literature review consists of three main steps, namely identification, article collection, article selection based on criteria, and main article selection. This method is called SLR (Systematic Literature Review) with the use of the SLR method, a systematic review and identification of journals can be carried out in each process. In addition, the SLR method can avoid subjective identification and it is hoped that the identification results can add to the literature in journal identification [7]. The first step is the identification and collection of articles. This step aims to get the initial search for the main article. The strategy used in this research is screening articles and the places where they appear must contain certain words, namely "implementation", "school-based environment", and "Adiwiyata" in the title, abstract, and keywords. The second stage is the selection of articles based on criteria. Then the final step is the selection of the main article. In this step, articles that have passed the previous step will be continued or reviewed for quality checking. The articles that pass will be used as the main article for analysis.

\section{RESULTS AND DISCUSSION}

The number of articles obtained in the initial collection of articles from the search for direct knowledge or insight 40 articles. Of the 40 articles obtained, 20 articles met the criteria produced in this study. Thus, another article was excluded from this study. Finally, after quality checking, there were 20 articles used as the main study.

\subsection{Environmental Policy}

Based on the literature review, this study found that there are 4 policies for implementing environmentally sound schools. Namely, environmentally friendly policies, environmentallybased curricula, participatory environmental activities, and management of environmentally-friendly facilities. The formulation of environmentally sound policies in schools refers to the Adiwiyata Guidelines book regarding the components and standards of environmentally sound policies. The policy was formulated by the Adiwiyata Team with the assistance of the Principal [8]. Based on the Adiwiyata guidebook. Environmental policies must have a standard, namely a curriculum at the level of an Education unit containing efforts to protect and manage the environment and an activity plan and school budget containing programs for environmental protection and management. At the initial stage, an activity plan is drawn up which will be implemented for one year. These activities are related to the determination of school policies that are environmentally sound by covering the vision and mission of school goals, a curriculum structure that contains environmental values, socialization of the Adiwiyata program.

In general, policy implementation is more difficult because policy implementation is related to real situations that often change, here the active role of school residents is important in realizing the Adiwiyata program. The school principal has made an integrated Adiwiyata school program that involves all school members, both educators, educational staff, and students in a sustainable manner. Adiwiyata's assessment focuses on the influence or contribution that the school makes to the community or the surrounding environment [9]. [10] Design standards have been developed by various professional organizations to establish compliance criteria with acceptable levels of greening. Including materials, tools, policies, practices, and, in setting the school curriculum. From this, school policy is an important thing in environment-based school programs.

\subsection{Environmental-Based Curriculum}

According to the literature review, several standards must be possessed in the implementation of an environment-based curriculum, namely that educators have competence in developing environmental learning activities, and students who carry out learning activities about environmental protection and management. For more details on the successful implementation of an environment-based curriculum, it can be seen in the following table.

From the explanation above, it can be said that the environment-based curriculum can be implemented by the active role of all school members in developing environment-based learning activities. So that environmental-based learning competencies can be realized and felt by school residents. 
Table.1 Success factors of environmental-based curriculum

\begin{tabular}{|c|c|c|}
\hline Standards & Implementation & Reference \\
\hline \multirow[t]{4}{*}{$\begin{array}{l}\text { a. Educators have the competence } \\
\text { in developing environmental } \\
\text { learning activities }\end{array}$} & $\begin{array}{l}\text { Developing environment-based } \\
\text { learning by raising local issues or } \\
\text { global issues, then it can be applied } \\
\text { in the lesson plan. }\end{array}$ & [11] \\
\hline & $\begin{array}{l}\text { Curriculum development is } \\
\text { characterized by the identification } \\
\text { of local environmental issues. } \\
\text { Learning planning utilizes the } \\
\text { environment school as a learning } \\
\text { resource in the form of a Learning } \\
\text { Implementation Plan (RPP) } \\
\text { concerning the } 2013 \text { curriculum. }\end{array}$ & {$[12],[13]$} \\
\hline & $\begin{array}{l}\text { Adiwiyata coaches guide subject } \\
\text { teachers to include environmental } \\
\text { activities in lesson plans and as a } \\
\text { form of environmental care. }\end{array}$ & [14] \\
\hline & $\begin{array}{l}\text { The active role of parents is to } \\
\text { exemplify a caring attitude towards } \\
\text { the environment and parents give } \\
\text { warnings to students who take } \\
\text { action to damage the environment } \\
\text { while at home. }\end{array}$ & [15] \\
\hline \multirow[t]{2}{*}{$\begin{array}{l}\text { b. Students carry out learning } \\
\text { activities about the protection and } \\
\text { management of environmental }\end{array}$} & $\begin{array}{l}\text { Efforts to behave competently } \\
\text { towards the environment. Starting } \\
\text { from covering the participants' } \\
\text { pleasure in solving problems and } \\
\text { completing tasks. }\end{array}$ & [16] \\
\hline & $\begin{array}{l}\text { Learning competence is achieved by } \\
\text { students if the learning process } \\
\text { activities have been designed by the } \\
\text { teacher to involve students to take a } \\
\text { role active in the learning process. }\end{array}$ & [17] \\
\hline
\end{tabular}

\subsection{Characteristic Participatory Environmental Activities}

Are environmental activities participatory are activities that involve the school community and the surrounding communities to provide good benefits for people in schools, communities, and the environment.
In participatory environmental activities, standards include implementing planned environmental protection and management activities for school residents and forging partnerships in the framework of environmental protection and management with various parties. The implementation of environmental activities participatory in schools can be integrated into student habituation activities in activities daily at 
school and extracurricular activities. The role of environmental education for school members in realizing the Adiwiyata program [12]. [18] In environmental protection and management activities, such as composter, nursery, classroom picket, implementation of the $3 \mathrm{R}$ program, and others.

Environmental problems generally have an effect on global warming, depletion of the ozone layer, use of hazardous materials and waste, degradation of water resources and wetlands, forest destruction, urbanization, and population growth. Environmental problems that arise due to increased human intervention in nature have brought threatening risks to life on earth [19]. [20] Students' awareness of the environment can be seen from the activeness of students in participating in activities Go Green School. Students who are active in activities Go Green School will always maintain and preserve the school environment such as participating in the maintenance and management of the school environment by implementing classroom cleanliness pickets, producing waste according to type, maintaining plants in the school garden, managing waste $(3 R)$ in the waste bank schools, as well as making recycled products.

Then use the land and facilities according to environmental principles through nurseries, Green House, waste management, and others. The next criterion is the creativity and innovation of school members in the protection and management of the environment through sanitation management, a publication of works of art, a publication of scientific works. Then develop extracurricular activities related to environmental preservation and management, for example, activities that involve creativity and innovation of students who utilize used goods that have a selling value [21]. So that school residents play an active role in participatory-based environmental activities.

\subsection{Management of Environmental Friendly Facilities}

Several obstacles in the implementation of the Adiwiyata program, such as the lack of love for school residents for the maintenance of existing facilities and infrastructure in schools, have not been properly cared for because the availability of facilities and infrastructure is still underutilized [22]. Maintenance of existing facilities and infrastructure in schools is the responsibility of the entire academic community. Efforts for existing facilities and infrastructure are always in good condition and not easily damaged, it is necessary to have the awareness of all personnel in this school so that they have a sense of responsibility for the facilities and infrastructure owned by the school
[23]. 2 standards must be met in the management of facilities and infrastructure, namely: a) conformity of the availability of facilities and infrastructure to the standards of Adiwiyata infrastructure management, b) efforts to improve the quality of management and utilization of Adiwiyata infrastructure facilities [24].

For the first standard regarding the suitability of the availability of facilities and infrastructure with Adiwiyata management standards [12], that schools are obliged to provide facilities and infrastructure to support the implementation of environmental education, among others: schools make improvements to the quality of environmental management, schools try to save on electrical energy resources, water, and waste management by recycling organic waste. There are several collaborations to care about waste with school residents, to improve the quality of the school environment, namely: (1) school policies, including increasing the capacity of human resources for managing waste and regulations for schools that care about waste; (2) waste management curriculum, namely the development of a waste management module, handouts, and posters; (3) participatory-based activity waste treatment by making a fuss caring about waste; (4) Availability of waste management sites in increasing scores from moderate to very good and the development of a waste management curriculum that includes the development of a waste management syllabus and lesson plans as well as extracurricular activities [25].

The second standard regarding the availability of Adiwiyata-based facilities and infrastructure includes: (a) composting activities; (b) utilization and treatment of water and school gardens; (c) availability of greenhouses; (d) availability of family medicinal plants; (e) availability of fish ponds and (f) availability of infiltration wells. Based on the guidebook Adiwiyata, the availability of 6 (six) facilities and infrastructure to support environment-based learning means that the school has reached the number 5 as the maximum score. So based on this, it is appropriate to provide 6 components of facilities and infrastructure to support learning [12]. Also, schools must have a waste bank to be an activity extracurricular for students to increase love for the environment. [26] Whereas a waste bank is waste generated from unused goods or goods (waste) or is still reused by the owner, and a waste bank is used to store waste, both organic and inorganic waste. Furthermore, organic waste is recycled into compost, while inorganic waste such as mineral water bottles, iron, glass, plastics, used cloth or clothes, used tires, cans, etc. from industrial waste can be reduced and reused as raw materials for manufacturing. souvenirs or for sale. The proceeds from the sale of processed organic fertilizers and souvenirs are used to fund extracurricular activities 
and environmental protection and management.

\section{CONCLUSION}

The Adiwiyata Program is a program of the Minister of Environment and the Minister of Education and Culture to make them aware of loving the surrounding environment from an early age. In the aspect of managing/developing environmentally friendly supporting facilities, it consists of six components, the first component is the use of school support facilities for environmental learning media. The second component, management of supporting facilities and school facilities that are environmentally friendly. The third component is the efforts to manage sanitation facilities. The fourth component, implementation efforts to save natural resources. The fifth component, efforts to improve canteen services and healthy food. The sixth component, waste management efforts.

\section{REFERENCES}

[1] P. K. Maji, Environment Related Behaviour of The Students Who are Visually Impaired, Journal of Education and Human Development 3(2) (2014) 793-808.

[2] W. P. Louw, Green Curriculum: Sustainable Learning in Higher Education, Internasional Review Research Open Distance Learning 14 (1) (2013) $1 . \quad$ DOI: http://doi.org/10.19173/Irrodl.V14i1.1310

[3] N. Aprilia, Evaluasi pengelolaan sarana pendukung yang ramah lingkungan pada program adiwiyata di SMP Muhammadiyah di Kota Yogyakarta, in: Prosiding Seminar Nasional Pendidikan Biologi, Universitas Muhammadiyah Malang, Malang. 2015, pp. 742-748.

[4] I. Maryani, Evaluasi Pelaksanaan Program Sekolah Adiwiyata, Jurnal Pemikiran dan Pengembangan SD 1(3) (2014) 225-229.

[5] D. E. Gordon And H. Aia, Green Schools As High Performance Learning Facilities, National Clearinghouse for Educational Facilities, 2010, pp. 1-16.

[6] Y. Isnaeni, Implementasi Kebijakan Sekolah Peduli dan Berbudaya Lingkungan di SMP Negeri 3 Gresik, Jurnal Kebijakan dan Pengembangan Pendidikan 1 (2013) 166-172. DOI: https://doi.Org/10.22219/Jkpp.V1i2.1565

[7] E. Triandini, S. Jayanatha, A. Indrawan, G. Werla Putra, And B. Iswara, Metode Systematic Literature Review Untuk Identifikasi Platform
Dan Metode Pengembangan Sistem Informasi di Indonesia, Indonesian Journal of Information. System 1(2) (2019) 63. DOI: http/org.doi/10.24002/Ijis.V1i2.1916.

[8] N. L. Hidayatun, Studi Deskriptif Pelaksanaan Program Adiwiyata di SD Muhamadiyah Tonggalan Klaten Descriptive Study: Implementation of The Adiwiyata Program In Elementary School of Muhammadiyah, pp. 945958.

[9] Ellen Landriany, Implementasi Kebijakan Adiwiyata dalam Upaya Mewujudkan Pendidikan Lingkungan Hidup di SMA Kota Malang, Jurnal Kebijakan dan Pengembangan Pendidikan 2 (2014) 82-88. DOI: https://doi.org/10.22219/jkpp.v2i1.1739

[10] T. C. Chan, An Examination of Green School Practices in Atlanta Schools, Online Submission, 2013, Pp. 1-46.

[11] J. Boeve-De Pauw And P. Van Petegem, The Effect of Flemish Eco-Schools on Student Environmental Knowledge, Attitudes, and Affect, Internasional Journal of Science Education 33(11) (2011) 1513-1538. DOI: http://doi.org/10.1080/09500693.2010.540725

[12] T. Yusnidar, D. Liesnoor, And E. Banowati, Peran Serta Warga Sekolah dalam Mewujudkan Program Adiwiyata di SMP Wilayah Semarang Barat, Journal of Educational Social Studies 4(1) (2015) 1-7. DOI: http://doi.org/10.15294/Jess.V4i1.6865

[13] T. Setiyoningsih, Pengelolaan Pembelajaran Ipa Berbasis Lingkungan Di Smpn 1 GabusGrobogan, Jurnal Manajemen Pendidikan 12(1) (2017) $1 . \quad$ DOI: http://doi.org/10.23917/Jmp.V12i1.2970

[14] S. Nuzulia, S. Sukamto, and A. Purnomo, Implementasi Program Adiwiyata Mandiri dalam Menanamkan Karakter Peduli Lingkungan Siswa, Sosio-Didaktika Social Science Education Journal 6(2) (2020) 155-164, DOI: http://doi.org/10.15408/Sd.V6i2.11334

[15] U. N. Rokhmah, Pelaksanaan Program Adiwiyata Sebagai Upaya Pembentukan Karakter Peduli Lingkungan Siswa di Madrasah Ibtidaiyah, Al Qalam Jurnal Ilmiah Keagamaan dan Kemasyarakatan 13(1) (2019) 67. DOI: http://doi.org/10.35931/Aq.V0i0.133

[16] R. De Young, New Ways to Promote Proenvironmental Behavior: Expanding And Evaluating Motives for Environmentally Responsible Behavior, Journal of Social Issues 
56(3) (2000) 509-526. DOI: http/doi.org/10.1111/0022-4537.00181.

[17] S. Alimah, Model Eksperiensial Jelajah Alam Sekitar sebagai Strategi Pengembangan Kompetensi Mahasiswa Calon Guru Biologi, Jurnal Pendidikan dan Pembelajaran Universitas Negeri Malang 21(2) (2014) 155-164.

[18] I. K. Pradini, B. Sudjanto, And N. Nurjannah, Implementasi Program Sekolah Adiwiyata dalam Peningkatan Mutu Pendidikan di SD N Tanah Tinggi 3 Kota Tangerang, Journal Green Growth dan Manajemen Lingkungan 7(2) (2019) 122-132.

DOI: http/doi.org/10.21009/Jgg.072.03.

[19] B. D. Altunoğlu, E. Atav, And S. Sönmez, The Investigation of Environmental Risk Perception and Attitudes towards The Environment In Secondary School Students, Turkish Online Journal Education Technology (2017) 436-444.

[20] E. P. Azrai, D. V. Sigit, And M. Puji, The Correlation Between Environmental Awareness and Students Participation in Go Green School Activity at Adiwiyata's School, Biosfer Journal Pendidikan Biologi 10(2) (2017) 7-11. DOI: http/doi.org/10.21009/Biosferjpb.10-2.2

[21] T. C. G. Tompodung, S. B. Rushayati, and M. N. Aidi, Efektivitas Program Adiwiyata Terhadap Perilaku Ramah Lingkungan Warga Sekolah Di Kota Depok, Jurnal Pengelolaan Sumber daya Alam Dan Lingkungan 8(2) (2018) 170-177.
DOI: http/doi.org/10.29244/Jpsl.8.2.170-177

[22] F. Amrullah And M. J. Susilo, Identifikasi sarana dan prasarana pendukung pelaksanaan sekolah adiwiyata di SMA Negeri Kota Yogyakarta, in: Prosiding Symbion (Symposium on Biology Education), Universitas Ahmad Dahlan, Yogyakarta, 2019, pp. 316-322.

[23] H. Hartoni, Impelementasi Manajemen Sarana dan Prasarana di Sekolah Menengah Kejuruan, Al-Idarah Jurnal Kependidikan Islam 8(1) (2018) 178 ,

DOI: http://doi.org/10.24042/Alidarah.V8i1.3088

[24] S. Catra Rahmadhani Putri, Pengelolaan Sarana dan Prasarana Berbasis Adiwiyata di Sma Negeri 1 Gresik, Jurnal Inspirasi Manajemen Pendidikan 3(3) (2014) 1-8.

[25] Y. Krisnawati, . Susilowati, M. H. I. Almuhdar, F. Rochman, And E. Budiasih, The Implementation Of Students' Campaign Program to Form Adiwiyata School In Malang, Indonesia, Internasional Journal of Research Studies Education 4(4) (2015) 53-65. DOI: http://doi.org/10.5861//jirse.2015.1041

[26] Warju, S. P. Harto, Soenarto, M. D. Hartmann, And I. K. P. B. S. Nurjannah, Evaluating The Implementation of Green School (Adiwiyata) Program: Evidence from Indonesia, Internasional Journal of Environmental Science Education 12(6) (2017) 1483-1501. 